\title{
INTEGRATED NUTRIENT MANAGEMENT ON WEED DYNAMICS OF COTTON BASED CROPPING SYSTEMS IN SOUTH INDIA
}

\author{
S. Marimuthu ${ }^{1}$ and P. Subbian \\ Department of Agronomy, Agricultural Research Station, Pattukkottai \\ Thanjavur District, Tamil Nadu, 614602, India
}

\begin{abstract}
Field experiments were conducted at the farm of Tamil Nadu Agricultural University, Coimbatore, India during 2007 and 2008 to assess the weed population, dry matter production, weed smothering efficiency and yield of seed cotton in a cotton based cropping system with conjunctive use of NPK and bioinoculants. Cotton intercropped with Sesbania along with application of Azospirillum and Pseudomonas recorded the lowest weed population and weed dry matter production. The maximum weed suppression of 54.5 and $44 \%$ was observed in cotton + Sesbania system as compared to pure crop of cotton during both the years. The maximum cotton equivalent yield of 2052 and $1895 \mathrm{~kg} \mathrm{ha}^{-1}$ was recorded in cotton + onion system which was at par with cotton + Sesbania system with cotton equivalent yield of 2010 and $1894 \mathrm{~kg} \mathrm{ha}^{-1}$ during 2007 and 2008, respectively. Combined application of $100 \%$ recommended dose of NPK and bioinoculants recorded maximum cotton equivalent yield of 2460 and $2190 \mathrm{~kg} \mathrm{ha}^{-1}$ during 2007 and 2008, respectively.
\end{abstract}

Key words: Cotton, intercrops, weeds, weed smothering efficiency, NPK

\section{INTRODUCTION}

Cotton is one of the important commercial crops of India. Cotton is grown by four million farmers in an area of 7.4 million hectares. India occupies the foremost position in acreage, which is almost $25 \%$ of the global cotton area. However, as the productivity is very low, India's contribution to the total world production is only $9 \%$ as compared to $22 \%$ from China and $19.4 \%$ from U.S (FAO, 2006). Poor agronomic practices, boll shedding, imbalanced use of organic and inorganic fertilizers largely contribute to low productivity of cotton in India. Soil resource base is degraded below a critical level and newer crop varieties or hybrids are not able to yield beyond a level, which is primarily determined by the level of native soil fertility. A nutrient budgeting study on cotton showed that the calculated nutrient balances of $\mathrm{N}$ and $\mathrm{K}$

\footnotetext{
${ }^{1}$ Corresponding author email: agrimuthu76@rediffmail.com
}

Received: 06.06.2012 
were negative causing low yield of cotton (Surendran and Murugappan, 2006). Due to slow germination and initial growth, wide spacing, slow lateral spread, high nutrient and moisture requirement, long duration and diversity in weed flora, cotton generally suffers heavily from weed infestation. Hence, successful weed control is essential for economical cotton production.

Inorganic fertilizers have contributed to environmental damage such as nitrate pollution and hence, legumes grown in intercropping are regarded as an alternative and sustainable way of introducing $\mathrm{N}$ into lower input agro ecosystems (Fustec et al., 2010). The use of legume in mixtures contributes some nitrogen to the non-legume component and some residual nitrogen to the following crops (Adu-Gyamfi et al., 2007), besides having a direct control over the establishment of weeds. The main pathway of conservation of other nutrients is return and decomposition of crop residues (Rahman et al., 2009). Control of weeds is also important to increase the efficiency of the applied fertilizers. Yadav et al. (1991) reported that nutrient availability to crop can be increased by timely and effective control of weeds. The present study was undertaken to assess the weed population and weed smothering efficiency in cotton based cropping system with conjunctive use of NPK and bioinoculants.

\section{MATERIALS AND METHODS}

Field experiments were conducted during 2007 and 2008 at eastern block farm, Tamil Nadu Agricultural University, Coimbatore, India. The soils of the experimental fields were sandy clay loam in texture low in available $\mathrm{N}\left(182 \mathrm{~kg} \mathrm{ha}^{-1}\right), \mathrm{P}_{2} \mathrm{O}_{5}(11.5 \mathrm{~kg}$ $\mathrm{ha}^{-1}$ ) and $\mathrm{K}_{2} \mathrm{O}\left(453 \mathrm{~kg} \mathrm{ha}^{-1}\right)$. The irrigation water had EC of $3.76 \mathrm{dSm}^{-1}$ and $\mathrm{pH}$ of 6.7. The mean maximum temperature during the crop period was 31.5 and $31^{\circ} \mathrm{C}$ and minimum temperature was 20.6 and $20.2^{\circ} \mathrm{C}$ in 2007 and 2008, respectively. The mean relative humidity was 87.3 and $86 \%$, and the total rainfall received during the experimental period was $428 \mathrm{~mm}$ in 25 rainy days, and $353 \mathrm{~mm}$ in 16 rainy days during 2007 and 2008, respectively.

The experiments were carried out in split-plot design with three replications. Treatments consisted of four Cropping systems, i.e., $\mathrm{M}_{1}$ : Cotton alone, $\mathrm{M}_{2}$ : Cotton + Sesbania (Sesbania aculeata), $\mathrm{M}_{3}$ : Cotton + Greengram and $\mathrm{M}_{4}$ : Cotton + Onion in main plots and five nutrient management practices viz., $\mathrm{S}_{1}$ : Azospirillum + Pseudomonas, $\mathrm{S}_{2}$ : $50 \%$ recommended NPK, $\mathrm{S}_{3}: 100 \%$ recommended NPK (80:17.5:33.2 kg ha $\left.{ }^{-1}\right), \mathrm{S}_{4}:$ 50\% recommended NPK+ Azospirillum + Pseudomonas and $\mathrm{S}_{5}: 100 \%$ recommended NPK + Azospirillum + Pseudomonas in sub- plots. Cotton var. MCU 12 was sown at a spacing of 75 x 30 cm @ two seeds per hill on one side of the ridge. The seed rate was $7.5 \mathrm{~kg}$ of delinted seed ha ${ }^{-1}$. For intercropping systems, dibbling of cotton seeds was done on one side of the ridge and simultaneously in opposite side, intercrops (Sesbania: Sesbania aculeata, Greengram: Vigna radiata and Onion (aggregatum): Allium cepa) were sown at 1:1 
ratio. Intercrops Sesbania and greengram were sown simultaneously and onion was sown after irrigation on the same day. The crops were raised under irrigated condition. The seeds were sown after treating with Azospirillum and Pseudomonas as per treatments. Details of crop sowing and harvesting dates are given in table 1 .

Farmyard manure @ $12.5 \mathrm{t} \mathrm{ha}^{-1}$ (containing 0.5, 0.09, 0.38 \% of total N, P and $\mathrm{K}$ respectively) was applied as a common dose to all plots. Nitrogen, phosphorus and potassium were applied as urea $(46 \% \mathrm{~N})$, rock phosphate $(6.98 \% \mathrm{P})$ and muriate of potash $(49.8 \% \mathrm{~K})$, respectively. For $\mathrm{S}_{1}, \mathrm{~S}_{4}$ and $\mathrm{S}_{5}$ Azospirillum and Pseudomonas were applied both as seed treatment and soil application at the rate of $80 \mathrm{~g}$ and $10 \mathrm{~g}$ $\mathrm{kg}^{-1}$ of seed, respectively. Commercially available Biofertilizer of Azospirillum and Pseudomonas produced by Tamil Nadu Agricultural University with the minimum viable cell count of $5 \times 10^{9} \mathrm{cfu} \mathrm{g}^{-1}$ and $5 \times 10^{8} \mathrm{cfu} \mathrm{g}^{-1}$ respectively were used. For soil application, Azospirillum@2 kg ha ${ }^{-1}$ and Pseudomonas @ $2.5 \mathrm{~kg} \mathrm{ha}^{-1}$ were mixed with $50 \mathrm{~kg}$ farmyard manure, $50 \mathrm{~kg}$ of soil and applied at 30 DAS (days after sowing).

Nitrogen was applied in three splits viz., $50 \%$ at 18 DAS, $25 \%$ at 45 DAS and remaining $25 \%$ at 60 DAS. Entire phosphorus was applied basally and potassium was applied in two equal splits at 18 DAS and 45 DAS as per treatment schedule. The green manure i.e Sesbania (containing 3.2, 0.26, and $0.99 \%$ of total N, P and K, respectively) was incorporated in the interspaces of cotton crop at 45 DAS at the time of earthing up. For intercrop, no additional fertilizer was applied in both years. Pendimethalin @ $1.5 \mathrm{~kg} \mathrm{ha}^{-1}$ was applied at 3 DAS followed by earthing up at 45 DAS for effective control of annual broad leaved and grassy weeds like Trianthema portulacastrum and Cynodon dactylon.

Weed count was recorded species wise at 20, 40 and 80 DAS using $0.25 \mathrm{~m}^{-2}$ quadrat from four places in each plot and expressed as $\mathrm{m}^{-2}$ as suggested by Burnside and Wicks,1965. The observed weeds were classified as grasses: (Cynodon dactylon (L.) Pers,, Dactyloctenium aegyptium Beauv and Chloris barbata Sw), sedges (Cyperus rotundus (L.) and broad leaved weeds (Digera arvensis (Forsk), Trianthema portulacastrum (L.), Parthenium hysterophorus, Flaveria australasica (Hook), Commelina bengalensis (L.), Amaranthus viridis (L.) and Datura metal. In each plot, quadrate was put in four places at random and the above ground portions of the weeds were removed. Weed samples were sun dried and then oven dried at $75^{\circ} \mathrm{C}$ till a constant weight was attained and dry weight of weed was expressed in $\mathrm{kg}$ $\mathrm{ha}^{-1}$.

Weed Smothering Efficiency (WSE) was worked out by using the formula mentioned below to assess the effect of intercrops on the smothering of weeds:

$$
\text { WSE (\%) }=\frac{\text { WDS - WDI }}{\text { WDS }}
$$


Where,

WDS $=$ Weed dry matter in sole crop

WDI $=$ Weed dry matter in the intercrop

The experimental data collected were subjected to statistical analysis as per methods suggested by Gomez and Gomez, 1984. Data on weed studies showed wide variation and hence they were subjected to $\log$ transformation $[\log (x+2)]$ as described by Bartlett (1947) and analyzed statistically. If significant, critical differences were worked out at five per cent level.

\section{RESULTS AND DISCUSSION}

\section{Weed population}

Weed population was significantly influenced by the Cropping systems at all the growth stages and it gradually decreased with the crop age. Lowest weed population of 32.33, 23.97, 18.91 and $41.60,33.20,37.60 \mathrm{~m}^{-2}$ at 20, 40 and 80 DAS was recorded with cotton + Sesbania system in 2007 and 2008, respectively. This might be due to the incorporated biomass of Sesbania which served as a thick layer of organic mulch preventing weed seed proliferation. The results are in conformity with the findings of Masiunas, 1998. Pure crop of cotton recorded maximum weed population which was found statistically at par with cotton + onion system in both the years (Table 3). Reduced plant density due to sparse foliage, non - branching, short stature and slow initial growth of onion might be the reason for more weed growth in cotton + onion systems. This is in conformity with the findings of Sivakumar, 2004.

Higher weed growth was recorded at 20 DAS with $100 \%$ NPK and bioinoculants, due to higher and continuous availability of plant nutrients, resulting in more weed infestation. But at later stage, the weed growth was reduced due to smothering effect of the base crop. Integrated Nutrient Management (INM) practices also exhibited significant difference in weed population in both the years with minimum weed population of 70.42, 34.87, 27.20 and 82.58, 40.89, $36.37 \mathrm{~m}^{-2}$ was recorded at 20, 40 and 80 DAS in first and second year respectively with application of bioinoculants alone. Maximum weed population of 96.83 and $110.73 \mathrm{~m}^{-2}$ was recorded at 20 DAS with $100 \%$ NPK + bioinoculants but it was at par with $100 \%$ NPK alone during 2007. The weed population was maximum with combined application of $100 \%$ NPK and bioinoculants which was followed by application of $100 \%$ NPK alone in both the years. The interaction between cropping systems and nutrient management practices on weed population was not significant in both the years.

The data on population of grasses, sedges and broad leaved weeds at 20, 40 and 80 DAS are presented in tables 4 and 5, respectively. In both the years, the broad leaved weeds dominated the total population of weeds followed by grasses and sedges. 
Cotton intercropped with Sesbania recorded minimum grassy weed population of 14.93, 11.00, 7.20 and 19.93, 15.93, $16.33 \mathrm{~m}^{-2}$ at 20, 40 and 80 DAS but it was followed by cotton + greengram system. The maximum population of grassy weeds was recorded with sole crop of cotton in both the years. INM practices with application of Azospirillum and Pseudomonas exerted positive influence on grassy weed population in both the years. Integrated use of $100 \%$ recommended NPK with bioinoculants recorded maximum population of grassy weeds of 44.50, 25.16, 30.50 and 53.08, 30.50, $24.33 \mathrm{~m}^{-2}$ at 20, 40 and 80 DAS which was followed by application of $100 \%$ recommended NPK alone during first and second year, respectively.

Significant reduction in the population of sedge was observed under intercropping systems over sole cropping of cotton at all the growth stages. Cotton + Sesbania recorded the lowest sedge population of 5.80, 4.33, 5.07 and 7.80, 4.47, $7.93 \mathrm{~m}^{-2}$ at 20, 40 and 80 DAS during 2007 and 2008, respectively. The maximum sedge weed population was recorded with sole crop of cotton in both the years. INM practices with application of Azospirillum and Pseudomonas had significantly reduced the population of sedge weed (12.58, 6.25, 7.33 and 15.67, 5.25, $7.50 \mathrm{~m}^{-2}$ at 20, 40 and 80 DAS during first and second year, respectively). Combined application of $100 \%$ recommended NPK with bioinoculants recorded maximum population of sedge weed followed by application of $100 \%$ NPK alone during first and second year, respectively. .

Cotton + Sesbania recorded the lowest broad leaved weed population of 9.67, 8.67, 6.60 and 13.86, 13.13, $13.67 \mathrm{~m}^{-2}$ at 20, 40 and 80 DAS in first and second year, respectively. The maximum population of broad leaved weeds was recorded under sole cropping followed by cotton + onion systems. INM practices also significantly influenced the population of broad leaved weeds at all the stages in both the years. Combined application of Azospirillum and Pseudomonas registered the lowest broad leaved weed population of 21.00, 12.67, 9.50, and 27.33, 15.83, $14.00 \mathrm{~m}^{-2}$ at 20, 40 and 80 DAS during first and second year respectively. The maximum broad leaved weeds population was recorded by combined application of $100 \%$ recommended NPK with bioinoculants in both the years. The interaction between cropping systems and nutrient management practices on weed population was not significant in both the years.

\section{Weed dry matter production}

Intercrops had a mitigating effect on dry matter production of weeds than sole crop in both the years (Figures 1 and 2). Cotton intercropped with Sesbania recorded minimum weed dry matter production of $82.00,91.00$ and $81.00,106.00 \mathrm{~kg} \mathrm{ha}^{-1}$ at 20 and 40 DAS during 2007 and 2008 respectively as compared to other cropping systems. Similar trend was observed at 80 DAS. The maximum weed dry matter production 20, 40 and 80 DAS was recorded by sole crop of cotton. The weed dry matter production was influenced by different INM practices in both the years of study. Application of bioinoculants alone registered the lowest weed dry matter 
production of 116, 170, 94 and 116, 182, $102 \mathrm{~kg} \mathrm{ha}^{-1}$ at 20, 40 and 80 DAS in 2007 and 2008 respectively. The maximum weed dry matter production was recorded with application of $100 \%$ NPK along with bioinoculants in both the years. But combined application of 50\% NPK along with bioinoculants recorded lesser weed dry matter production than $100 \%$ NPK alone. However, it was at par with 50\% NPK alone. The interaction between cropping systems and nutrient management practices on weed dry matter production was not significant.

\section{Weed smothering efficiency}

Considerable variation in weed smothering efficiency was observed due to cropping systems and nutrient management practices during first and second year (Figures 3 and 4). In general all the intercropping systems improved the weed smothering efficiency. The maximum weed smothering efficiency was recorded at 40 DAS as compared to 20 and 80 DAS. Among the various cropping systems, Cotton + Sesbania recorded maximum weed smothering efficiency in both years. Sesbania and greengram suppressed the weeds considerably and established themselves as an efficient tool in minimizing the weed population. Similar results in earlier studies were reported by Vaiyapuri et al., 2010 and Pandian and Viola, 2001. Such reduction in weed growth by intercrops might be ascribed to the larger canopy coverage of Sesbania, which intercepted more light and also competed with other inputs. Moreover, certain glucosinolates which are present in the roots, stems and leaves of green manure crops are broken down into Isothiocyanates and other chemicals, which are responsible for killing or suppressing the weed seeds as allele chemicals by Andy McGuire Lauzier, 2003. Liebman and Dyck, 1993 reported that spatial diversity achieved through intercropping could markedly reduce weed population density and biomass production.

The weed smothering efficiency was higher with combined application of 50\% NPK and bioinoculants than 100\% recommended NPK alone. Cotton + Sesbania system treated with bioinoculants produced maximum weed smothering efficiency of 56.52, 75.16, 57.74 and 57.58, 72.22, $55.29 \%$ at 20, 40 and 80 DAS in first and second year, respectively. The least weed smothering efficiency was registered by cotton + onion system with 100\% NPK and bioinoculants.

\section{Cotton seed and equivalent yield}

Significant improvement in seed cotton yield and cotton equivalent yield (CEY) was observed due to various cotton based cropping systems. The highest cotton seed yield was recorded from $\mathrm{M}_{2}$ treatment, even higher than sole cotton. Seed yield was reduced in intercrop combination and maximum in cotton + onion combination. The maximum CEY of 2052 and $1895 \mathrm{~kg} \mathrm{ha}^{-1}$ were recorded by cotton + onion system but it was at par with cotton + Sesbania with 2010 and $1894 \mathrm{~kg} \mathrm{ha}^{-1}$ in 2007 and 2008, respectively (Table 6). Green manuring with Sesbania might have helped in better suppression of weeds and high weed smothering efficiency, slow and steady nutrient release because of synergistic effect of organic $\mathrm{N}$ from incorporated 
Sesbania as well as timely application of inorganic N (Das et al., 1998). Intercrops that are effective at suppressing weeds capture a greater share of available resources than sole crops and could be more effective in pre- empting resources by weeds and suppressing weed growth (Lithourgidis et al., 2011).

Different levels of NPK with bioinoculants had significantly influenced CEY in both the years. Among the nutrient management practices, combined application of $100 \%$ recommended dose of NPK and bioinoculants recorded the maximum cotton equivalent yield of 2460 and $2190 \mathrm{~kg} \mathrm{ha}^{-1}$ in 2007 and 2008, respectively. Better cotton crop growth with higher nutrition suppressed the weeds. Integration of 50\% recommended NPK with bioinoculants proved its superiority with maximum CEY over application of $50 \%$ recommended NPK alone. The combination of cotton + Sesbania system closely followed by cotton + onion with $100 \%$ recommended NPK + Azospirillum + Pseudomonas performed better in terms of CEY compared to other treatments.

Better response to integration of organic and inorganic fertilization might be due to synergistic effect. At later stage, the weed growth was reduced due to smothering effect of the base crop and increased cotton yield and yield attributing parameters analogous to the results of Hosmath et al., 2011. Incorporation of green manure in intercropping system ensured better supply of nitrogen increasing the nutrient use efficiency and also, the yield of cotton. Besides incorporation of leguminous (green manure) crop has beneficial effect on soil fertility.

\section{CONCLUSION}

The study indicated that cotton intercropped either with Sesbania or greengram coupled with weed control measures of pre-emergence application of pendimethalin @ $1.5 \mathrm{~kg}$ a.i ha ${ }^{-1}$ at 3 DAS followed by one earthing up at 45 DAS were effective in enhancing the yield of seed cotton and cotton equivalent yield compared to the sole crop of cotton. Combined application of $100 \%$ recommended dose of NPK and bioinoculants recorded maximum cotton equivalent yield of 2460 and $2190 \mathrm{~kg} \mathrm{ha}^{-1}$ during 2007 and 2008, respectively. 
Table 1: Crop sowing and harvest details of the field experiment

\begin{tabular}{c|l|c|c}
\hline Sl. No. & Crop & First crop & Second crop \\
\hline 1 & Cotton & & \\
& Date of sowing & 16.08 .2006 & 27.08 .2007 \\
\multirow{2}{*}{2} & Date of Harvesting & 22.02 .2007 & 25.02 .2008 \\
& Daincha (Local) & & \\
& Date of sowing & 16.08 .2007 & 27.08 .2007 \\
\multirow{2}{*}{3} & Date of harvest & 29.09 .2007 & 10.10 .2007 \\
& Greengram & & \\
& Date of sowing & 16.08 .2007 & 27.08 .2007 \\
\multirow{2}{*}{4} & Date of harvest & 24.10 .2007 & 04.11 .2007 \\
& Onion & & \\
& Date of sowing & 16.08 .2007 & 27.08 .2007 \\
& Date of harvest & 03.11 .2007 & 14.11 .2008 \\
\hline
\end{tabular}

Table 2: Major weed flora of the experimental field

\begin{tabular}{lll}
\hline Scientific name & Habitat & Family \\
\hline A. Grasses & & \\
Cynodon dactylon (L.) Pers. & Perennial & Poaceae \\
Dactyloctenium aegyptium Beauv & Annual & Poaceae \\
Chloris barbata Sw & Perennial & Poaceae \\
B.Sedge & & \\
Cyperus rotundus (L.) & Perennial & Cyperaceae \\
C. Broad leaved weeds & & \\
Digera arvensis (Forsk) & Annual & Amaranthaceae \\
Trianthema portulacastrum (L.) & Annual & Aizoaceae \\
Parthenium hysterophorus & Annual & Asteraceae \\
Flaveria australasica (Hook) & Annual & Compositae \\
Commelina bengalensis (L.) & Annual & Commelinaceae \\
Amaranthus viridis (L.) & Annual & Amaranthaceae \\
Datura metal & Annual & Solanaceae \\
\hline
\end{tabular}


Table 3: Effect of cropping systems and nutrient management practices on weed population

\begin{tabular}{|c|c|c|c|c|c|c|}
\hline \multirow{3}{*}{ Treatment } & \multicolumn{3}{|c|}{2007} & \multicolumn{3}{|c|}{2008} \\
\hline & \multicolumn{3}{|c|}{ DAS } & \multicolumn{3}{|c|}{ DAS } \\
\hline & 20 & 40 & 80 & 20 & 40 & 80 \\
\hline \multicolumn{7}{|l|}{ Main plot } \\
\hline \multirow[t]{2}{*}{$\mathrm{M}_{1}$} & 120.80 & 52.72 & 45.17 & 128.06 & 59.28 & 52.17 \\
\hline & (2.07) & $(1.71)$ & $(1.64)$ & (2.09) & (1.76) & (1.71) \\
\hline \multirow[t]{2}{*}{$\mathrm{M}_{2}$} & 32.33 & 23.97 & 18.91 & 41.60 & 33.20 & 37.60 \\
\hline & $(1.49)$ & (1.35) & $(1.24)$ & (1.59) & $(1.51)$ & (1.56) \\
\hline \multirow[t]{2}{*}{$\mathrm{M}_{3}$} & 78.67 & 43.31 & 31.09 & 99.73 & 50.51 & 40.27 \\
\hline & (1.89) & (1.63) & $(1.48)$ & (1.99) & (1.69) & (1.59) \\
\hline \multirow[t]{2}{*}{$\mathrm{M}_{4}$} & 115.13 & 55.53 & 40.38 & 127.32 & 58.77 & 51.73 \\
\hline & $(2.05)$ & $(1.73)$ & $(1.59)$ & $(3.09)$ & $(1.75)$ & (1.70) \\
\hline$\pm \mathrm{SE}$ & 9.00 & 3.56 & 2.14 & 9.94 & 2.51 & 0.94 \\
\hline $\mathrm{CD}(\mathrm{P}=0.05)$ & 22.03 & 8.72 & 5.23 & 24.31 & 6.11 & 2.30 \\
\hline \multicolumn{7}{|l|}{ Sub plot } \\
\hline \multirow[t]{2}{*}{$\mathrm{S}_{1}$} & 70.42 & 34.87 & 27.20 & 82.58 & 40.89 & 36.37 \\
\hline & $(1.79)$ & $(1.51)$ & (1.39) & $(1.85)$ & (1.59) & (1.55) \\
\hline \multirow[t]{2}{*}{$\mathrm{S}_{2}$} & 81.42 & 40.33 & 30.50 & 92.87 & 46.15 & 41.33 \\
\hline & $(1.84)$ & (1.58) & $(1.44)$ & $(1.91)$ & (1.64) & (1.60) \\
\hline \multirow[t]{2}{*}{$\mathrm{S}_{3}$} & 95.41 & 47.01 & 36.66 & 107.79 & 53.22 & 49.13 \\
\hline & $(1.92)$ & (1.64) & $(1.53)$ & (1.99) & (1.71) & (1.68) \\
\hline \multirow[t]{2}{*}{$\mathrm{S}_{4}$} & 89.58 & 42.42 & 33.67 & 101.92 & 48.42 & 43.82 \\
\hline & (1.89) & (1.59) & (1.49) & (1.96) & (1.67) & (1.62) \\
\hline \multirow[t]{2}{*}{$\mathrm{S}_{5}$} & 96.83 & 54.81 & 41.27 & 110.73 & 63.53 & 56.57 \\
\hline & $(1.93)$ & $(1.69)$ & $(1.59)$ & $(2.01)$ & 1.78 & 1.74 \\
\hline$\pm \mathrm{SE}$ & 1.16 & 1.47 & 0.52 & 1.43 & 0.96 & 1.00 \\
\hline $\mathrm{CD}(\mathrm{P}=0.05)$ & 2.36 & 2.99 & 1.07 & 2.92 & 1.95 & 2.04 \\
\hline
\end{tabular}

$\mathrm{M}_{1}$ : Cotton alone, $\mathrm{M}_{2}$ : Cotton + Sesbania (Sesbania aculeata), $\mathrm{M}_{3}$ : Cotton+ Greengram and $\mathrm{M}_{4}$ : Cotton+ Onion; $\mathrm{S}_{1}$ : Azospirillum + Pseudomonas, $\mathrm{S}_{2}: 50 \%$ recommended NPK, $\mathrm{S}_{3}: 100 \%$ recommended NPK (80:40:40 kg N, $\mathrm{P}_{2} \mathrm{O}_{5}$ and $\mathrm{K}_{2} \mathrm{O}$ ha $^{-1}$ ), $\mathrm{S}_{4}: 50 \%$ recommended NPK+ Azospirillum + Pseudomonas and $\mathrm{S}_{5}: 100 \%$ recommended NPK + Azospirillum + Pseudomonas. Figures in parenthesis indicate log $(\mathrm{x}+2)$ transformed value 
Table 4: Effect of cropping systems and nutrient management practices on species wise weed population in 2007

\begin{tabular}{|c|c|c|c|c|c|c|c|c|c|}
\hline \multirow{2}{*}{ Treatment } & \multicolumn{3}{|c|}{ Grasses } & \multicolumn{3}{|c|}{ Sedges } & \multicolumn{3}{|c|}{ Broad leaved weeds } \\
\hline & 20 DAS & 40 DAS & 80 DAS & 20 DAS & 40 DAS & 80 DAS & 20 DAS & 40 DAS & 80 DAS \\
\hline $\mathrm{M}_{1}$ & $56.73(1.75)$ & $24.27(1.38)$ & $17.07(1.22)$ & $21.67(1.33)$ & $9.47(0.97)$ & $12.13(1.08)$ & $36.27(1.55)$ & $20.07(1.29)$ & $15.80(1.16)$ \\
\hline $\mathrm{M}_{3}$ & $36.13(1.55)$ & $20.17(1.29)$ & $11.80(1.06)$ & $14.20(1.15)$ & $7.87(0.89)$ & $8.40(0.92)$ & $23.47(1.36)$ & $15.53(1.18)$ & $10.80(1.03)$ \\
\hline $\mathrm{M}_{4}$ & $53.00(1.72)$ & $25.53(1.34)$ & $15.33(1.18)$ & $20.87(1.31)$ & $10.07(0.94)$ & $10.93(1.03)$ & $34.47(1.52)$ & $19.00(1.27)$ & $14.00(1.14)$ \\
\hline $\operatorname{SEd} \pm$ & $2.67(0.001)$ & $0.96(0.002)$ & $0.69(0.002)$ & $1.12(0.005)$ & $0.39(0.007)$ & $0.42(0.007)$ & $1.74(0.002)$ & $0.66(0.004)$ & $0.62(0.007)$ \\
\hline $\mathrm{S}_{1}$ & $33.83(1.47)$ & $16.08(1.18)$ & $19.50(0.97)$ & $12.58(1.04)$ & $6.25(0.77)$ & $7.33(0.83)$ & $21.00(1.27)$ & $12.67(1.08)$ & $9.50(0.94)$ \\
\hline $\mathrm{S}_{2}$ & $37.50(1.51)$ & $18.50(1.24)$ & $22.17(1.03)$ & $14.67(1.11)$ & $7.23(0.83)$ & $8.17(0.87)$ & $24.33(1.33)$ & $14.58(1.14)$ & $10.67(0.99)$ \\
\hline $\mathrm{S}_{3}$ & $43.75(1.59)$ & $21.67(1.31)$ & $25.50(1.11)$ & $17.30(1.19)$ & $8.42(0.89)$ & $9.92(0.97)$ & $28.67(1.40)$ & $17.00(1.21)$ & $12.75(1.08)$ \\
\hline $\mathrm{S}_{4}$ & $41.42(1.56)$ & $19.58(1.27)$ & 23.33 (1.08) & $16.17(1.15)$ & $7.75(0.87)$ & $9.08(0.93)$ & $26.83(1.37)$ & $15.25(1.16)$ & $11.67(1.03)$ \\
\hline $\mathrm{S}_{5}$ & $44.50(1.60)$ & $25.16(1.37)$ & 30.50 (1.18) & 17.42 (1.19) & $10.01(0.97)$ & $11.17(1.03)$ & $29.00(1.41)$ & $19.58(1.26)$ & $14.42(1.15)$ \\
\hline
\end{tabular}

$\mathrm{M}_{1}$ : Cotton alone, $\mathrm{M}_{2}$ : Cotton + Sesbania (Sesbania aculeata), $\mathrm{M}_{3}$ : Cotton+ Greengram and $\mathrm{M}_{4}$ : Cotton+ Onion; $\mathrm{S}_{1}$ : Azospirillum + Pseudomonas, $\mathrm{S}_{2}: 50 \%$ recommended NPK, $\mathrm{S}_{3}: 100 \%$ recommended NPK $\left(80: 40: 40 \mathrm{~kg} \mathrm{~N}, \mathrm{P}_{2} \mathrm{O}_{5}\right.$ and $\mathrm{K}_{2} \mathrm{O}$ ha $\left.^{-1}\right), \mathrm{S}_{4}: 50 \%$ recommended NPK + Azospirillum + Pseudomonas and $\mathrm{S}_{5}$ : $100 \%$ recommended NPK+ Azospirillum + Pseudomonas. Figures in parenthesis indicate log $(\mathrm{x}+2)$ transformed value 
Table 5: Effect of cropping systems and nutrient management practices on species wise weed population (No.m²) in 2008

\begin{tabular}{|c|c|c|c|c|c|c|c|c|c|}
\hline \multirow{2}{*}{ Treatment } & \multicolumn{3}{|c|}{ Grasses } & \multicolumn{3}{|c|}{ Sedges } & \multicolumn{3}{|c|}{ Broad leaved weeds } \\
\hline & 20DAS & 40DAS & 80DAS & 20DAS & 40DAS & 80DAS & 20DAS & 40DAS & 80DAS \\
\hline $\mathrm{M}_{1}$ & $61.53(1.78)$ & $28.40(1.45)$ & $22.40(1.34)$ & $24.33(1.38)$ & $7.67(0.88)$ & $11.00(1.03)$ & $42.27(1.62)$ & $23.13(1.36)$ & $18.40(1.26)$ \\
\hline $\mathrm{M}_{3}$ & $47.93(1.67)$ & $24.27(1.38)$ & $17.33(1.23)$ & $19.00(1.27)$ & $6.53(0.81)$ & $8.47(0.92)$ & $32.81(1.51)$ & $19.67(1.29)$ & $14.80(1.16)$ \\
\hline $\mathrm{M}_{4}$ & $61.00(1.72)$ & $28.20(1.43)$ & $22.27(1.34)$ & $24.21(1.35)$ & $7.61(0.86)$ & $10.80(1.02)$ & $42.03(1.60)$ & $22.93(1.34)$ & $17.53(1.27)$ \\
\hline SEd & $2.79(0.002)$ & $0.83(0.001)$ & $0.43(0.002)$ & $1.14(0.002)$ & $0.23(0.009)$ & $0.27(0.007)$ & $1.99(0.002)$ & $0.65(0.002)$ & $0.65(0.013)$ \\
\hline $\mathrm{S}_{1}$ & $39.67(1.53)$ & $19.50(1.27)$ & $15.58(1.18)$ & $15.67(1.13)$ & $5.25(0.70)$ & $7.50(0.86)$ & $27.33(1.37)$ & $15.83(1.18)$ & $14.00(1.13)$ \\
\hline $\mathrm{S}_{2}$ & 44.65 (1.59) & $22.17(1.33)$ & $17.83(1.24)$ & $17.75(1.18)$ & $6.08(0.77)$ & $8.75(0.93)$ & $30.67(1.43)$ & $18.17(1.24)$ & $15.92(1.19)$ \\
\hline $\mathrm{S}_{3}$ & $51.75(1.68)$ & $25.50(1.39)$ & $21.17(1.32)$ & $20.58(1.28)$ & $6.92(0.83)$ & $10.33(1.00)$ & $35.50(1.52)$ & $20.83(1.31)$ & $16.75(1.22)$ \\
\hline $\mathrm{S}_{4}$ & $48.83(1.64)$ & $23.33(1.35)$ & $19.00(1.27)$ & $19.33(1.24)$ & $6.33(0.79)$ & $9.34(0.96)$ & $33.75(1.48)$ & $18.92(1.26)$ & $17.83(1.23)$ \\
\hline $\mathrm{S}_{5}$ & 53.08 (1.69) & $30.50(1.47)$ & $24.33(1.38)$ & 21.00 (1.29) & $8.33(0.90)$ & 11.83 (1.07) & $36.58(1.54)$ & $24.83(1.38)$ & 16.00 \\
\hline
\end{tabular}

$\mathrm{M}_{1}$ : Cotton alone, $\mathrm{M}_{2}$ : Cotton + Sesbania (Sesbania aculeata), $\mathrm{M}_{3}$ : Cotton+ Greengram and $\mathrm{M}_{4}$ : Cotton+ Onion; $\mathrm{S}_{1}$ : Azospirillum + Pseudomonas, $\mathrm{S}_{2}: 50 \%$ recommended NPK, $\mathrm{S}_{3}: 100 \%$ recommended NPK (80:40:40 kg N, $\mathrm{P}_{2} \mathrm{O}_{5}$ and $\mathrm{K}_{2} \mathrm{O}$ ha $\left.{ }^{-1}\right), \mathrm{S}_{4}: 50 \%$ recommended NPK+ Azospirillum + Pseudomonas and $\mathrm{S}_{5}: 100 \%$ recommended NPK+ Azospirillum + Pseudomonas. Figures in parenthesis indicate log $(\mathrm{x}+2)$ transformed value 
Table 6: Effect of cropping systems and nutrient management practices on Seed cotton yield and Cotton Equivalent Yield $\left(\mathrm{Kg} \mathrm{ha}^{-1}\right)$ in 2007 and 2008

\begin{tabular}{|c|c|c|c|c|c|c|}
\hline \multirow[b]{2}{*}{ Treatments } & \multicolumn{3}{|c|}{2007} & \multicolumn{3}{|c|}{2008} \\
\hline & $\begin{array}{l}\text { Seed cotton } \\
\text { yield }\end{array}$ & $\begin{array}{c}\text { Intercrop } \\
\text { equivalent } \\
\text { yield }\end{array}$ & $\begin{array}{l}\text { Cotton } \\
\text { Equivalent } \\
\text { Yield }\end{array}$ & $\begin{array}{l}\text { Seed cotton } \\
\text { yield }\end{array}$ & $\begin{array}{c}\text { Intercrop } \\
\text { equivalent } \\
\text { yield }\end{array}$ & $\begin{array}{c}\text { Cotton } \\
\text { Equivalent } \\
\text { Yield }\end{array}$ \\
\hline \multicolumn{7}{|l|}{ Main plot } \\
\hline $\mathrm{M}_{1}$ & 1841 & - & 1841 & 1716 & - & 1716 \\
\hline $\mathrm{M}_{2}$ & 2010 & - & 2010 & 1894 & - & 1894 \\
\hline $\mathrm{M}_{3}$ & 1651 & 227 & 1878 & 1542 & 222 & 1764 \\
\hline $\mathrm{M}_{4}$ & 1583 & 469 & 2052 & 1479 & 416 & 1895 \\
\hline SEd & 34 & - & 32 & 32 & - & 37 \\
\hline $\mathrm{CD}(\mathrm{P}=0.05)$ & 83 & - & 82 & 79 & - & 90 \\
\hline \multicolumn{7}{|l|}{ Sub plot } \\
\hline $\mathrm{S}_{1}$ & 1208 & 107 & 1315 & 1171 & 109 & 1280 \\
\hline $\mathrm{S}_{2}$ & 1634 & 166 & 1800 & 1569 & 135 & 1704 \\
\hline $\mathrm{S}_{3}$ & 1965 & 207 & 2172 & 1840 & 190 & 2030 \\
\hline $\mathrm{S}_{4}$ & 1806 & 185 & 1991 & 1718 & 150 & 1868 \\
\hline $\mathrm{S}_{5}$ & 2227 & 233 & 2460 & 1983 & 207 & 2190 \\
\hline SEd & 51 & - & 58 & 56 & - & 51 \\
\hline $\mathrm{CD}(\mathrm{P}=0.05)$ & 104 & - & 119 & 115 & - & 103 \\
\hline
\end{tabular}

$\mathrm{M}_{1}$ : Cotton alone, $\mathrm{M}_{2}$ : Cotton + Sesbania (Sesbania aculeata), $\mathrm{M}_{3}$ : Cotton+ Greengram and $\mathrm{M}_{4}$ : Cotton+ Onion; $\mathrm{S}_{1}$ : Azospirillum + Pseudomonas, $\mathrm{S}_{2}: 50 \%$ recommended NPK, $\mathrm{S}_{3}: 100 \%$ recommended NPK (80:40:40 kg N, $\mathrm{P}_{2} \mathrm{O}_{5}$ and $\mathrm{K}_{2} \mathrm{O}^{-1}{ }^{-1}$ ), $\mathrm{S}_{4}: 50 \%$ recommended NPK+ Azospirillum + Pseudomonas and $\mathrm{S}_{5}: 100 \%$ recommended NPK + Azospirillum + Pseudomonas. 


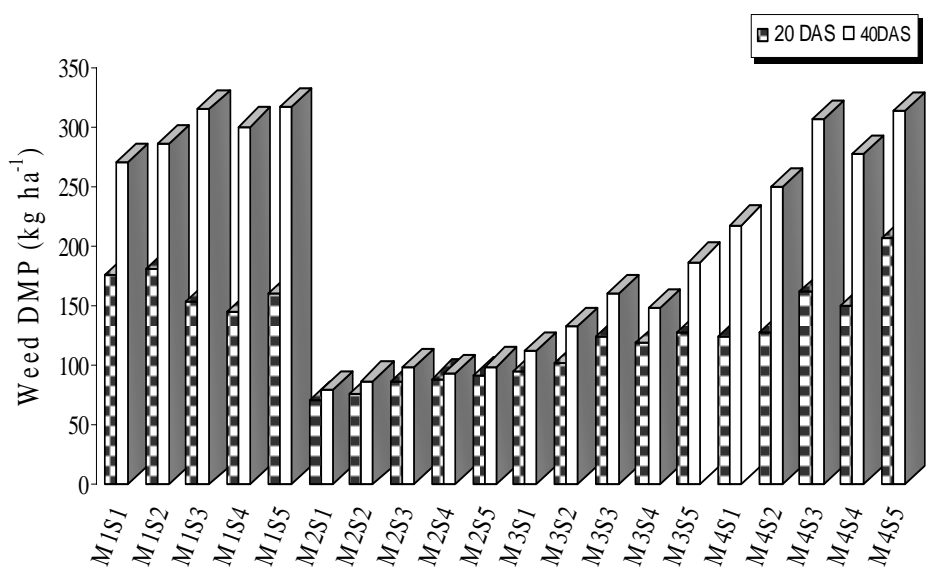

Fig.1. Effect of cropping systems and nutrient management on weed DMP in cotton (2007)

$\mathrm{M}_{1}$ : Cotton alone, $\mathrm{M}_{2}$ : Cotton + Sesbania (Sesbania aculeata), $\mathrm{M}_{3}$ : Cotton+ Greengram and $\mathrm{M}_{4}$ : Cotton+ Onion; $\mathrm{S}_{1}$ : Azospirillum + Pseudomonas, $\mathrm{S}_{2}: 50 \%$ recommended NPK, $\mathrm{S}_{3}: 100 \%$ recommended NPK (80:40:40 kg N, $\mathrm{P}_{2} \mathrm{O}_{5}$ and $\mathrm{K}_{2} \mathrm{O}$ ha $^{-1}$ ), $\mathrm{S}_{4}: 50 \%$ recommended NPK+ Azospirillum + Pseudomonas and $\mathrm{S}_{5}: 100 \%$ recommended NPK+ Azospirillum + Pseudomonas.

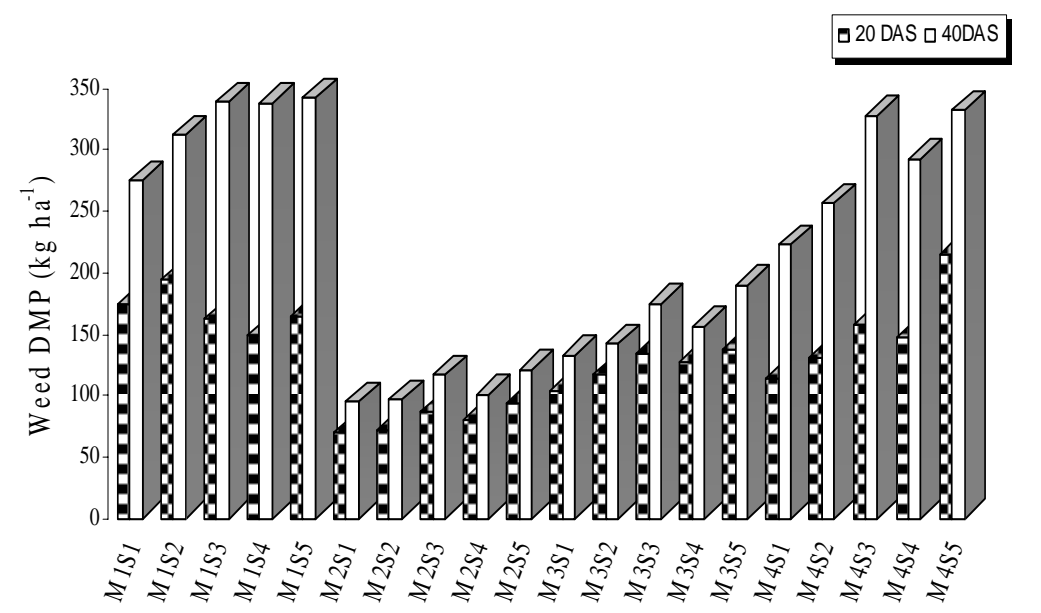

Fig.2.Effect of cropping systems and nutrient management on weed DMP in cotton (2008)

$\mathrm{M}_{1}$ : Cotton alone, $\mathrm{M}_{2}$ : Cotton + Sesbania (Sesbania aculeata), $\mathrm{M}_{3}$ : Cotton+ Greengram and $\mathrm{M}_{4}$ : Cotton+ Onion; $\mathrm{S}_{1}$ : Azospirillum + Pseudomonas, $\mathrm{S}_{2}: 50 \%$ recommended NPK, $\mathrm{S}_{3}: 100 \%$ recommended NPK (80:40:40 kg N, $\mathrm{P}_{2} \mathrm{O}_{5}$ and $\mathrm{K}_{2} \mathrm{O} \mathrm{ha}^{-1}$ ), $\mathrm{S}_{4}: 50 \%$ recommended NPK+ Azospirillum + Pseudomonas and $\mathrm{S}_{5}: 100 \%$ recommended NPK+ Azospirillum + Pseudomonas. 


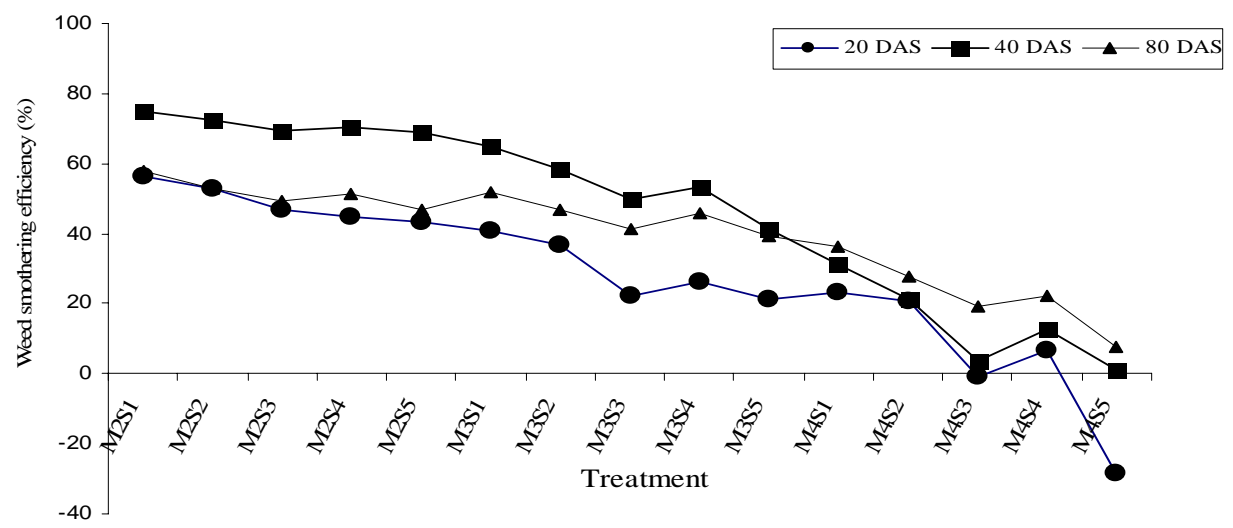

Fig. 3. Effect of cropping system and nutrient management on weed smothering efficiency in cotton (2007)

$\mathrm{M}_{1}$ : Cotton alone, $\mathrm{M}_{2}$ : Cotton + Sesbania (Sesbania aculeata), $\mathrm{M}_{3}$ : Cotton+ Greengram and $\mathrm{M}_{4}$ : Cotton+ Onion; $\mathrm{S}_{1}$ : Azospirillum + Pseudomonas, $\mathrm{S}_{2}: 50 \%$ recommended NPK, $\mathrm{S}_{3}: 100 \%$ recommended NPK (80:40:40 kg N, $\mathrm{P}_{2} \mathrm{O}_{5}$ and $\left.\mathrm{K}_{2} \mathrm{O}_{\text {ha }}{ }^{-1}\right), \mathrm{S}_{4}: 50 \%$ recommended NPK+ Azospirillum + Pseudomonas and $\mathrm{S}_{5}: 100 \%$ recommended NPK+ Azospirillum + Pseudomonas.

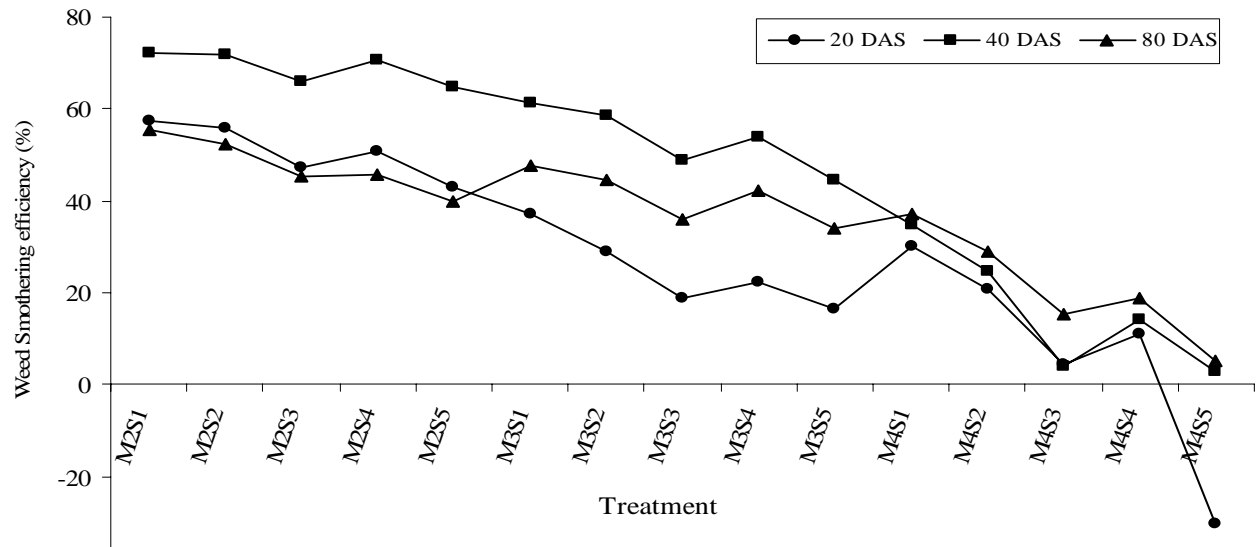

Fig. 4. Effect of cropping sysem and nutrient management on weed smothering efficiency in cotton (2008)

$\mathrm{M}_{1}$ : Cotton alone, $\mathrm{M}_{2}$ : Cotton + Sesbania (Sesbania aculeata), $\mathrm{M}_{3}$ : Cotton+ Greengram and $\mathrm{M}_{4}$ : Cotton+ Onion; $\mathrm{S}_{1}$ : Azospirillum + Pseudomonas, $\mathrm{S}_{2}: 50 \%$ recommended NPK, $\mathrm{S}_{3}: 100 \%$ recommended NPK (80:40:40 kg N, $\mathrm{P}_{2} \mathrm{O}_{5}$ and $\mathrm{K}_{2} \mathrm{O}$ ha $^{-1}$ ), $\mathrm{S}_{4}: 50 \%$ recommended NPK+ Azospirillum + Pseudomonas and $\mathrm{S}_{5}: 100 \%$ recommended NPK+ Azospirillum + Pseudomonas 


\section{REFERENCES}

Adu-Gyamfi JJ, Myaka FA, Sakala WD, Odgaard R, Vesterager JM, Hogh-Jensen H. 2007. Biological nitrogen fixation and nitrogen and phosphorus budgets in farmer- managed intercrops of maize-pigeonpea in semiarid southern and eastern Africa. Plant Soil, 295:127-136.

Andy McGuire Lauzier. 2003. Using green manures in Potato cropping systems. Washington State University. http;//grant-adams.wsu.edu.

Bartlett's, M. S. 1947. The use of transformations. Biometrics, 3: 1-2.

Burnside, O.C and G.A.Wicks. 1965. Effect of herbicides and cultivation treatments on yield components of dry land sorghum in Nebraska. Agronomy Journal, 57:21-24.

Das, R., D.K.Das and B.Das. 1998. Transformation of nitrogen in submerged soil in relation to yield and nutrition of rice as affected by sources and method of nitrogen application. Oryza, 35 (4): 338-342.

Gomez, K.A and A.A. Gomez. 1984. Statistical procedures for agricultural research-John Wiley and Sons, New York.

FAO 2006. FAO Statistical Database. Food and Agriculture Organization of the United Nations. http://faostat.fao.org.

Fustec J, Lesuffleur F, Mahieu S, Cliquet JB.2010. Nitrogen rhizodeposition of legumes. A review. Agron Sustain Dev. 30:57-66.

Hosmath, J A., D, P. Biradar and S.K.Deshpande.2011. Response of Bt Cotton to organic and inorganic nutrient management under rainfed and irrigated ecosystem. International Resource Journal of Plant Science,1:244-248.

Liebman. M and Dyck, E. 1993. Crop rotation and intercropping strategies for weed management. Ecol. Appl., 3: 92-122.

Lithourgidis, A.S., C.A. Dordas, C.A,Damalas and D.N. Vlachostergios.2011.Annual intercrops: an alternative pathways for sustainable agriculture. Australian Journal of Crop Science, 5(4):396-410.

Masiunas, M. 1998. Production of vegetable using cover crops and living mulching -A review. Journal of Vegetable Crop Production, 4 (1): 11-31.

Pandian, B.J and D. Viola. 2001. Weed management in Cotton based intercropping system under irrigated condition. Madras Agricultural Journal, 88 (10-12) 741-742.

Rahman MM, Amano T, Shiraiwa T. 2009. Nitrogen use efficiency and recovery from N fertilizer under rice based cropping systems. Australian Journal of Crop Science, 3:336-351

Sivakumar, S.D. 2004. Performance of vegetable intercropping systems and sources of nutrients supply on sustainable yield of rainfed cotton. Ph.D. diss. Agricultural college and Research Institute, Madurai. Tamil Nadu Agric Univ., Coimbatore. India.

Surendran U, Murugappan V. 2006. A micro and meso level modeling study for assessing sustainability in semi arid tropical agro ecosystem using NUTMON -Toolbox. Journal of Sustainable Agriculture, 29 (2):151 -179. 
Vaiyapuri, K., M. M.Amanullah, K. Rajendran and K. Sathyamoorthi. 2010. Intercropping unconventional green manures in cotton: An organic approach for multiple benefits - A review. Asian Journal of Plant Science, 9 (4):223-226.

Yadav, K,S., S.C. Deshmukh and R.P. Yadav. 1991. Response of hirsutum cotton to spacing and fertilizer levels in the hill zone of Assam. Ann. Agric. Res., 15: 7.

Yadav, B.D., Joon, R.K., Lodhi, G.P.and R.S.Sheoran, R.S.1991. Effect of agro management practices on the seed yield of clusterbean. Guar Research Annals, 7: 30-33. 